
$\frac{U B}{T 2}$
T2A

Th. R.R. 

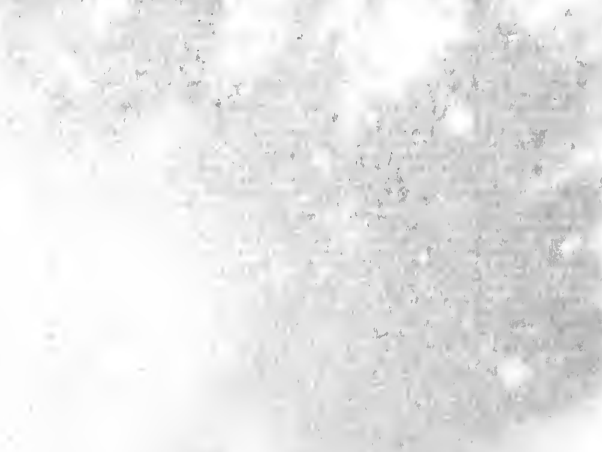

- Lla zpoung

inith denaghertymi affectionate bithay angratukations end good misher.

$$
4^{\text {th }} \text { Hay } 1904
$$




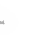


THE DIDACHE 



\section{THE DIDACHE OR}

THE TEACHING OF THE

TWELVE APOSTLES

TRANSLATED WITH NOTES

BY

G. C. ALLEN, M.A.

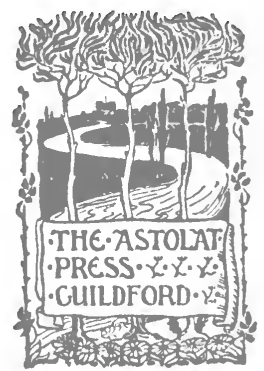

THE ASTOLAT PRESS

34 GREAT CASTLE ST.

LONDON W.

MDCCCCIII 
Th R.R.

SEP 291954 


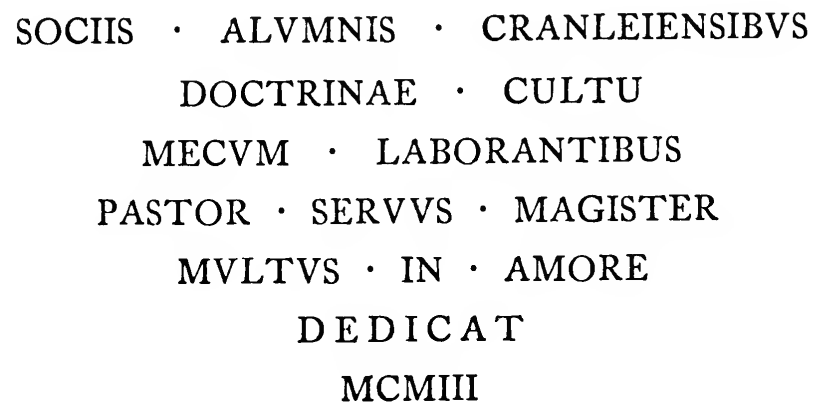




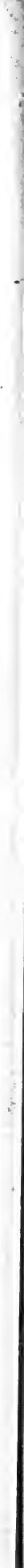




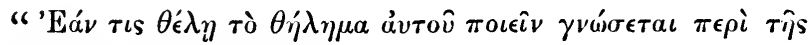
$\delta \iota \delta \alpha \chi \hat{\eta} \mathbf{s} . "-J o h n$ vii. I 7 . 



\section{PREFACE.}

$A^{\text {MONG the many editions of the Didache and com- }}$ mentaries thereon which have been issued since it was first brought to light some twenty years ago by Archbishop Bryennios, there yet seems room for one which, without competing either in learning or research with its great predecessors, may possibly fill a gap which they have left open. The present edition is simply an attempt to bring to the notice of those who have little opportunity for the study of Patristic literature, one of the most interesting and illuminating discoveries ever made in Patristic history. The "Teaching of the Twelve Apostles" is a brief work, not longer than the Epistle to the Galatians ; but its suggestiveness is great and varied. I have added only such notes and illustrations as seemed best fitted to show its relation to the Teaching of the New Testament and the beliefs and practices of the Early Christian Church. Yet even these have extended themselves more than I had contemplated, though I have had to leave unsaid much that one was tempted to insert. The comments and dissertations of Bryennios, Harnack, Schaff, Taylor, Heron, and Bishop Lightfoot's articles in the Expositor and elsewhere, form a mass of reading from which selection is not an easy task. By limiting the range of its purpose, however, it has been possible to keep the book within bounds, and I have to acknowledge with gratitude the charm and interest that I have found in the study of these authorities. It will be seen, I think, that I have not adopted their conclusions hastily or wholesale. But where I have ventured to differ from them it has been with diffidence, and with a full sense of the responsibility of so doing.

It remains to be said that the translation of the text was completed before I had seen Dr. Taylor's admirable version. It was taken up as an amusement for the leisure 
hours of vacation, and it is a satisfaction to find, on comparing the two, that I have differed from him in no important particular. One may confess, however, to being haunted by the refrain of such "Sortes Vergilianæ" as "sequitur patrem non passibus aquis," and "infelix puer atque impar congressus Achilli."

G. C. A.

MASTER's LODGE,

Cranleigh School. 


\section{INTRODUCTION.}

I.

\section{The Discovery of the Didache.}

IN the year 1873 , Philotheos Bryennios, Archbishop of

Nicomedia, found among the MSS. in the Jerusalem monastery of the Holy Sepulchre at Constantinople, a small, thick volume, covered with black leather, containing 120 leaves of vellum closely covered with Greek manuscript. The contents appeared to be all written by the same hand, and he was delighted to find, at the first glance, that they included copies of the first and second Epistles of Clement of Rome and the Epistle of Barnabas. He was so engrossed with these that he took no notice of the remaining portion of the book until 1880 , when he began to read the treatise which came next to the Clementine Epistles. This was no other than the "Teaching of the Twelve Apostles," and realizing at once its immense value and importance, he devoted all his spare time during the next three years to the study of it. In 1883 he published it with Prolegomena and notes written in modern Greek.

II.

The Importance of the Didache.

We find in the New Testament several references to a certain form of teaching imparted by the Apostles to their converts. This would, of course, at first have been oral, and would probably continue to exist even after the Gospels and Epistles were written. For example, in Acts ii. 42, we read that the converts "continued stedfastly in the Apostles' teaching and fellowship" (i

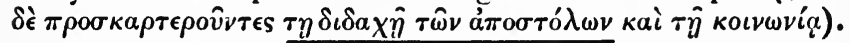
And in xvii. 19 of the same book we find the Athenians 
questioning St. Paul as to what this new teaching may be.

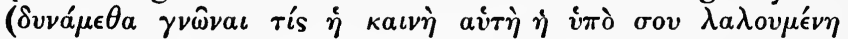
$\delta \iota \delta a \chi \eta^{\prime}$;). St. Paul exhorts Titus (i. 9) to "hold fast to the faithful word according to the teaching"

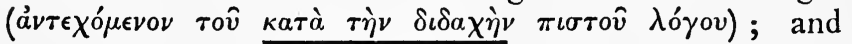
he is thankful that the Christians at Rome had become " obedient to that form of teaching whereunto they were

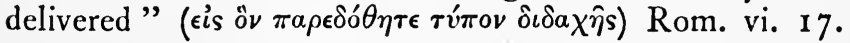
We find in the writings of the Fathers during the first five or six centuries of the Church's history, frequent reference to some work, called either the "Teaching" or "Teachings" of the Apostles; and there seems no doubt that such a treatise was widely known and held in much esteem. No copy was, however, extant, though it had been possible to divine from the various quotations and references in Patristic writings some idea of its character and extent. Amongst the shrewdest guesses was that of Archbishop Usher in 1644 , who predicted that if it were recovered it would be found to be a brief document, simple and practical, and free from the mystical and allegorizing element which enters so largely into the later sub-apostolic writings. We cannot claim with certainty that the recovered MS. represents the original form of the Teaching; but the best authorities are at least agreed that it is the source and inspiration of three of the most important of noncanonical works : the Epistle of Barnabas, the Ecclesiastical Canons and the Apostolical Constitutions.

Indeed, two years before its discovery a certain Roman Catholic scholar, Dr. Krawntzcky, had attempted to reconstruct from these three documents the older work from which they were supposed to be derived, and with such success that his reconstruction is almost identical in substance with the first part of the Didache.

The importance of the treatise lies in the fact that short as it is (not more than nine octavo pages) there is scarcely a question of any note in connection with the early Church, to which it does not contribute some light. 
The discovery has been called an epoch-making event. To quote Bishop Lightfoot (Expositor, January, I 885), "Its interest and importance have far exceeded our highest expectations. . . . . Of the genuineness of this document there can be no shadow of doubt."

The MS. discovered by Bryennios (says Dr. Taylor) is dated 6564 Anno Mundi, according to Greek reckoning. This is equivalent to I056 A.D., " two years after the division of Christendom into the rival Churches of East and West."

\section{III.}

\section{The Age of the Didache.}

The date of its composition may be inferred not less from its omissions than from its statements. It is silent as to usages in the Early Church which prevailed from the middle of the second century, as, for instance, the Baptismal observances, which it could scarcely have failed to notice had they been practised at the time of its compilation. There is no trace in it of the heresiesGnostic or Montanist-of the second century. The chapters on Church Organization do not recognize the distinction of the three Orders, which dates from about the middle of the second century; they speak, like St. Paul in his Epistles, only of " bishops" and "deacons." "Presbyters" are not named, because in the early days "bishops" and "presbyters" were synonymous. The Gospels are quoted, not as written documents; in fact, " the Gospel" is referred to as a whole, and, therefore, almost certainly in its oral form, no mention being made of Evangelists; and no New Testament books are quoted or referred to as Canonical Scripture, though several statements are taken from various Epistles.

Finally, the style and substance bear the mark of archaic simplicity. There is more affinity to the style and vocabulary of the New Testament than is found, so far as I am aware, in any other sub-apostolic document; 
and the practical, almost childlike, directness of the subject matter is in strong contrast with the grotesque and fanciful manner of other writings of similar date. One need only compare the Didache for a few moments with Barnabas, Hermas, and even Justin Martyr, to recognize the distance that separates them in language and thought. The first simple, direct, practical; the others mystical, visionary, full of far-fetched allegory and speculative interpretation. It is impossible to resist the conclusion that if the present form of the Didache is not actually that of the original Apostolic Teaching, it must at all events be referred to a period not later than the beginning of the second century, and, perhaps, as Dr. Taylor shows with good reason, even to the first.

IV.

Analysis of the Didache.

PART I.

Chapters I-V.

The Two Ways: one of Life and one of Death. I-IV. " The Way of Life."

I. A summary of duties taken chiefly from the Sermon on the Mount.

II. Negative commands, "the Second Commandment of the Teaching," forming with chapters iii. and iv. an expansion of the Second Table of the Law, the spirit, as well as the letter of obedience, being strongly insisted on. V. "The Way of Death."

A list of sins similar to those mentioned by our Lord in Mark vii. 21-23, and by St. Paul, Rom. i. 29-31, with special reference to the heathen immoralities to which the converts might be exposed.

VI. An exhortation to the right choice of life as exemplified in the previous chapters. 


\section{PART II.}

\section{Chapters VII-XVI.}

Instructions on the Sacraments, Fasting, Prayer, Church

Organization, Preparation for the Second Advent.

VII. On Baptism.

VIII. On Fasting and Prayer. (Example : the Lord's Prayer.)

IX., X. On the Agapé and Eucharist.

XI., XII., XIII. Directions as to the discernment and reception of the itinerant ministers of the Church.

XIV. Observance of the Lord's Day, with special. reference to the Eucharistic sacrifice.

XV. Appointment of local ministers of the Church. Exhortation to brotherly love.

XVI. The duty of watchfulness. Signs of the end. Antichrist. The fire of trial. Three signs preceding the Lord's Return. The Second Advent.

[The division of the Didache into chapters was made by Bryennios; the sub-division into verses by Harnack. The latter, though not wholly satisfactory, I have retained for the sake of convenience.] 



\section{THE TEACHING OF THE LORD THROUGH THE TWELVE APOSTLES TO THE GENTILES}

\section{CHAPTER I}

THERE are Two Ways : one of Life, and one of Comp. Deut. xxx. 15. Death; and there is much difference between the Jer. vii. ${ }^{13}$.

Two Ways. 2 The Way of Life then is this: first, 2 Pet. ii. 15. Thou shalt love God who hath made thee; secondly, Matt. xxii 37, 39 thy neighbour as thyself; and all things whatsoever Mark. xii $23,3 \mathbf{I}$ thou wouldest not should be done unto thee, do not Luke x. 25,27 . thou unto another. 3 And of these words the teaching is Comp. Matt. vii. I2. this: Bless them that curse you, and pray for your Luke vi. 3I. enemies, and fast for those that persecute you ; for what Luke vi. 27, 35 thank have ye if ye love them that love you ? do not even the Gentiles the same? But do ye love them which hate you, and ye shall not have an enemy. 4 Abstain from fleshly and bodily lusts; if any man give $\mathbf{1}$ Peter ii. Ir. thee a blow on thy right cheek, turn to him the other Matt. v. 39, 4r. also, and thou shalt be perfect. If any man shall compel thee to go one mile, go with him twain. If any man shall take thy cloke, give him thy coat also. If any Comp. 1 Cor. vi. 7 . man take from thee that which is thine own, ask it not again, for neither canst thou. 5 Give to every one that Matt. v. 42. asketh of thee and ask not again ; for the Father wills Luke vi. 30. that men give to all men out of what they have themselves received. Blessed is he who gives according to the commandment; for he is free of blame [but] woe to him that receiveth; for if being in need he receiveth he shall be free of blame; but he that receiveth, not being in need shall be punished. For wherefore received he it, and to what end? But coming under constraint* he * or 'discipline' or shall be examined concerning the things which he did; confinement. 
Matt. v. 26. Luke xii. 59.

Matt. xix 18,19 Mark x. 19.

Luke xviii. 20.

${ }^{*} \gamma \epsilon \nu \nu \eta \xi \theta \nu \tau a$

Matt. v. 33 .

I Cor. xiii. 5 . Jas. i. 8 .

John xvi. 8 .

Lev. xix. 26. and he shall not come out thence till he have paid the uttermost farthing. 6 But about this also it hath been said, Let thine alms sweat into thy hands until thou discernest unto whom thou givest.

\section{CHAPTER II}

NOW the second commandment of the teaching is 2 Thou shalt not kill, thou shalt not commit adultery, thou shalt not corrupt children, thou shalt not commit fornication, thou shalt not steal, thou shalt not use magic arts, thou shalt not use sorcery, thou shalt not destroy a child by abortion, neither shalt thou slay* him that is born. 'Thou shalt not covet thy neighbour's goods, 3 thou shalt not forswear thyself, thou shalt not bear false witness, thou shalt not speak evil, thou shalt not be mindful of evil, 4 thou shalt not be double-minded, neither double-tongued; for to be double-tongued is a snare of death. 5 Thy speech shall not be false ; it shall not be empty, or vain, or void, but fulfulled in action. 6 Thou shalt not be avaricious, neither rapacious, nor a hypocrite, nor malicious, nor over-weening. Thou shalt not take evil counsel against thy neighbour. 7 Thou shalt not hate any man; but some thou shalt reprove; and for some thou shalt pray; and some thou shalt love more than thy own soul.

\section{CHAPTER III}

MY son, flee from all evil and from all that is like unto it; 2 be not inclined to anger, for anger leadeth to murder; neither be a zealot, nor quarrelsome, nor passionate; for of all these things come murders. $3 \mathrm{My}$ son, be not lustful, for lust leadeth unto fornication; neither be of foul speech, nor of lofty eye ; for of all these things come adulteries. $4 \mathrm{My}$ son practise not augury, inasmuch as it leadeth unto idolatry; nor be an user of charms, nor an astrologer, nor an user of purifications, neither desire to look upon them; for of all these things cometh idolatry. $5 \mathrm{My}$ son, be not a liar; 


\section{THE TEACHING OF THE TWELVE APOSTLES}

inasmuch as lying leadeth unto theft; neither a moneylover, nor vain-glorious; for of all these things come thefts. $6 \mathrm{My}$ son, be not a murmurer, inasmuch as it $\mathbf{I}$ Cor. $x$. xo. leadeth unto blasphemy ; nor stubborn, nor evil-minded; for of all these things come blasphemies. 7 But be meek, for the meek shall inherit the earth ; 8 be long-suffering, Ps. 37 rr. Matt. v. 5 . and merciful and guileless and peaceable, and good, and always in fear of the words which thou hast heard. 9 Thou shalt not exalt thyself, neither shalt thou give arrogance to thy soul; thy soul shall not be joined with the lofty, but with the just and lowly shalt thou converse. in The nneratione [of Godl that hafoll than abals ah a..

\section{CORRIGENDA}

PAGE

2 Margin $\gamma \epsilon \nu \nu \eta \theta^{\prime} \epsilon \tau \alpha$

I 6 Alexandria

I 8 Hosanna \&c. should be printed with next par.

$23 \sigma \alpha \beta \beta a \tau i \zeta o v \tau \epsilon s$

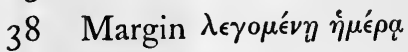

4I Margin $\pi a ́ \nu \tau \alpha$

receive 6 but withholdeth them for giving. $\ddagger$ If thou hast $\downarrow$ or ' when asked to it in thy hands thou shalt give a ransom for thy sins $\$$ give.' it in thy hands thou shalt give a ransom for thy sins. $\oint$ or 'if thou hast, thou 7 Thou shalt not hesitate to give, neither when thou shalt give with thy givest shalt thou murmur $\|$; for thou shalt know who is hands.' the fair recompenser of the reward. 8 Thou shalt not \| or 'grudge.' turn away from him that is in need, but thou shalt share Comp. ii Cor. ix. 7 . all things with thy brother and shalt not call anything thine own; for if ye are sharers in that which is incorruptible, how much more in the things which are corruptible? 9 Thou shalt not take away thy hand from thy son or from thy daughter, but from their youth up thou 
Matt. v. 26. Luke xii. 59 .

Matt. xix 18,19 Mark x. 19.

Luke xviii. 20. and he shall not come out thence till he have paid the uttermost farthing. 6 But about this also it hath been said, Let thine alms sweat into thy hands until thou discernest unto whom thou givest.

\section{CHAPTER II}

NOW the second commandment of the teaching is 2 Thou shalt not kill, thou shalt not commit adultery, thou shalt not corrupt children, thou shalt not commit fornication, thou shalt not steal, thou shalt not use magic arts, thou shalt not use sorcery, thou shalt not

Lev, xix. 26.

$\mathbf{M}^{\mathrm{Y}}$ son, flee from all evil and from all that is like unto it; 2 be not inclined to anger, for anger leadeth to murder; neither be a zealot, nor quarrelsome, nor passionate; for of all these things come murders. $3 \mathrm{My}$ son, be not lustful, for lust leadeth unto fornication; neither be of foul speech, nor of lofty eye ; for of all these things come adulteries. $4 \mathrm{My}$ son practise not augury, inasmuch as it leadeth unto idolatry ; nor be an user of charms, nor an astrologer, nor an user of purifications, neither desire to look upon them; for of all these things cometh idolatry. $5 \mathrm{My}$ son, be not a liar; 
inasmuch as lying leadeth unto theft; neither a moneylover, nor vain-glorious; for of all these things come thefts. $6 \mathrm{My}$ son, be not a murmurer, inasmuch as it ${ }_{1}$ Cor, $x_{1}$ ro. leadeth unto blasphemy ; nor stubborn, nor evil-minded; for of all these things come blasphemies. 7 But be meek, for the meek shall inherit the earth ; 8 be long-suffering, Ps. 37 Ir. Matt. v. 5 . and merciful and guileless and peaceable, and good, and always in fear of the words which thou hast heard. 9 Thou shalt not exalt thyself, neither shalt thou give arrogance to thy soul; thy soul shall not be joined with the lofty, but with the just and lowly shalt thou converse. Io The operations [of God] that befall thee shalt thou accept as good, knowing that without God nothing cometh to pass.

\section{CHAPTER IV}

MY son, night and day shalt thou remember him that speaketh unto thee the word of God; and thou shalt honour him as God, for where * the power of the * lit. ' whence.' Lord $t$ is proclaimed there is the Lord. 2 And thou shalt for 'the Lordship.' seek out day by day the faces of the saints that thou mayest rest upon their words. 3 Thou shalt not desire division, but thou shalt make peace between them that Comp. Matt. v. 9. are at strife: thou shalt judge righteously, thou shalt not respect persons in reproving for transgressions. 4 Thou shalt not waver in spirit whether it shall be yea or no. $5 \mathrm{Be}$ not one that stretcheth forth his hands to Comp. Prov. xvi. 6. receive 6 but withholdeth them for giving. $\ddagger$ If thou hast $\downarrow$ or 'when asked to it in thy hands thou shalt give a ransom for thy sins. $\$$ give.' 7 Thou shalt not hesitate to give, neither when thou shalt give with thy givest shalt thou murmur $\|$; for thou shalt know who is hands.' the fair recompenser of the reward. 8 Thou shalt not $\|$ or 'grudge.' turn away from him that is in need, but thou shalt share Comp. ii Cor. ix. 7 . all things with thy brother and shalt not call anything thine own; for if ye are sharers in that which is incorruptible, how much more in the things which are corruptible? 9 Thou shalt not take away thy hand from thy son or from thy daughter, but from their youth up thou 
shalt teach them the fear of God. Io Thou shalt not in thy bitterness lay commands upon thy bondman or thy maidservant who hope in the same God; lest at any time they may cease to fear Him who is the God over both. For He cometh not to call men according to outward appearance, but to those whom the Spirit hath made

Eph. vi. 5. ready for Him. I I And ye servants be subject unto

Col, iii. 22. your masters, as unto an image of God in shamefastness and fear. I 2 Thou shalt hate all hypocrisy and all that is not pleasing unto the Lord. I3 Thou shalt not forsake the commandments of the Lord, but thou shalt keep what thereto thou hast received, neither adding nor taking

Comp. Deut. iv. 2, and away. I4 Thou shalt confess thy sins in the congrega-

Rev. $x$ xii. 18,19 . tion, and thou shalt not come to thy prayer * with an evil * or 'to the place of ther' as in Acts conscience. 'This is the Way of life. xvi. 13.

\section{CHAPTER V}

BUT the Way of Death is this : first of all it is evil and full of cursing, murders, adulteries, covetous desires, fornications, thefts, idolatries, witchcrafts, sorceries, plunderings, false witnessings, hypocrisies, duplicity, guile, arrogance, malice, stubbornness, greed, foulness of speech, envy, insolence, pride, boasting ; 2 persecutors of the good, hating truth, loving falsehood; not acknowledging the

Rom. xii. 9. for 'intent upon.' reward of righteousness, not clcaving to that which is good neither to righteous judgment; watchful $t$ not toward good but toward evil; from whom meekness and patience are far removed; loving vain things, seeking after recompense, not pitying the poor, not sorrowing with the sorrow-laden, not acknowledging their Maker ; murderers of children, destroyers of the image of God, turning away from the needy, grieving the afflicted; advocates of the rich, lawless judges of the poor; wholly given to sin. May ye be delivered, my children from all these. 


\section{CHAPTER VI}

GEE that no man lead thee astray from this Way of the Lam. iii. 27. $S_{\text {Teaching; }}$ since he teacheth thee apart from God. Matt. xi. 29, 30. 2 For it thou canst bear all the yoke of the Lord thou shalt be perfect; but if thou canst not, do that which thou canst. 3 Now concerning food, bear what thou canst; Acts xv. 20. but refrain utterly from meat offered to idols, for it is a Cor. x. 28 . service of dead gods.

\section{CHAPTER VII}

A ND concerning baptism, baptize after this manner : A Having first recited all these precepts baptize into the name of the Father and of the Son and of the Holy Ghost in living water ; 2 but if thou hast not living water, baptize into other water; and if thou canst not in cold water then baptize in warm. 3 But if thou hast neither, pour out water upon the head thrice, into the name of the Father and of the Son and of the Holy Ghost. 4 And Matt. xxviii. 19. before the baptism let the baptizer and the baptized fast, and any others that are able; but thou shalt order the baptized to fast one or two days beforehand.

\section{CHAPTER VIII}

A ND your fastings, let them not be with the Matt. vi. 16 . $A$ hypocrites; for they fast on the second and fifth days of the week ; but do ye fast on the fourth day and on the preparation. 2 Neither pray ye as the hypocrites, Matt. vi. 5. but as the Lord commanded in His Gospel, even so pray ye :

OUR Father Which art in HEaven, Hallowed BE Thy Name,

THY KINGDOM COME,

THY WILL BE DONE,

As IN HEAVEN SO ALSO UPON EARTH;

Matt. v. 9-13. 
GIVE US THIS DAY OUR DAILY BREAD, AND FORGIVE US OUR DEBT As WE ALSO FORGIVE OUR DEBTORS; AND BRING US NOT INTO TEMPTATION BUT DELIVER US FROM EVIL; For THINe IS THE POWER AND THE GLORY FOR EVER. Thrice a day thus pray ye.

\section{CHAPTER IX}

* or Son.

Acts iv. 25.

for Son ;

Acts iv. 27.

Phil. ii. 7 .

for Son.

Comp. Mark xiii. 27.

Matt. vii. 6.

John vi. 12.

John i. 14.

Rev. vii. 15 ; xxi. 3. II or Son.
$A$ ND concerning the Service of Thanksgiving give ye thanks after this manner: 2 First concerning the Cup: We thank Thee, our Father, for the holy Vine of David Thy Servant, ${ }^{*}$ which Thou didst make known to us through Jesus Thy Servant + ; to Thee be the glory for ever. 3 And concerning the bread that is broken: We thank Thee, our Father, for the life and knowledge which Thou didst make known to us through Jesus Thy Servant $\ddagger$; to Thee be the glory for ever. 4 Even as this bread that is broken was scattered upon the mountains and being gathered together was made one, so let Thy Church be gathered together from the ends of the earth into Thy kingdom, for Thine is the glory and the power through Jesus Christ for ever. 5 And let none eat or drink of your Thanksgiving but those that have been baptized into the Name of the Lord; for indeed the Lord hath said concerning this, give not that which is holy unto the dogs.

\section{CHAPTER $X$}

$A$ ND after that ye have been filled, give ye thanks after this manner: $2 \mathrm{We}$ thank Thee Holy Father for Thy Holy Name which Thou has made to dwell in our hearts, and for the knowledge and for faith and immortality which Thou didst make known to us through Jesus Thy Servant $\|$; to Thee be the glory for evry. 3 Thou Almighty Ruler didst create all things for The 
Name s sake; Thou didst give both food and drink unto Rev. iv. I1. men for enjoyment, that they may give thanks unto Thee. But to us Thou didst freely grant spiritual food and drink and life eternal through Thy Servant.* $4 \mathrm{We}$ give *or Son. thanks to Thee before all things that Thou art mighty. 5 Thine is the glory for ever. Remember $O$ Lord Thy Church to deliver it from all evil, and perfect it in Thy Love; and gather it from the four winds, even Matt. xxiv. 31 . Thy Church which hath been sanctified, into Thy Kingdom which Thou hast prepared for it ; for Thine is the Matt. xxv. 34 . power and the glory for ever.

6 Let Thy grace come and let this world pass away ; Hosanna to the God of David. Whosoever is holy, let I Cor. xvi. 22. him come, and whosoever is not, let him repent. Phil. iv. v. Maranatha.t Amen. for 'the Lord cometh.'

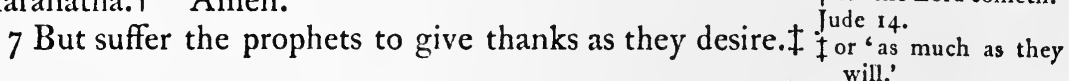

\section{CHAPTER XI}

WhOSOEVER then shall come and teach you all these things that have been aforesaid, receive him;

2 but if the teacher himself be prevented and teach 2 John 10. another $\$$ doctrine so as to overthrow it, hearken not to or teaching. him ; $\|$ but if he so teach as to increase righteousness and \|Compare Luke ix. knowledge of the Lord receive him as the Lord. 3 And Matt. x. $_{40}$. concerning the apostles and prophets according to the John xiii. 20. decree of the Gospel so do ye ; 4 but let any apostle that cometh unto you be received as the Lord, 5 howbeit he shall abide but one day; but if there be need, the next day also; but if he abide three days he is a false prophet. 6 And let not the apostle when he goeth forth take anything save bread to last until the place where he next sojourneth. But if he ask for money he is a false prophet. 7 And ye shall not try nor judge any prophet that Matt. xii. $3^{1}, 3^{2}$. speaketh in the spirit ; for every sin shall be forgiven, but Mark iii. 28, 29. this sin shall not be forgiven. 8 Howbeit not everyone Luke xii. ro. that speaketh in the spirit is a prophet, except he have the ways of the Lord. Therefore by their ways shall ${ }^{1}$ John ${ }^{1}{ }^{16}$. 
Matt. vii. 16-20, and the false prophet and the prophet be known. 9 And xii. 34, 35. every prophet that appointeth a table in the spirit shall not eat thereof, otherwise he is a false prophet. Io And if any prophet that teacheth the truth doeth not the things that he teacheth he is a false prophet. I I And any prophet approved and true, that doeth things for a worldly mystery of the church but teacheth not men to do as he himself doeth, he shall not be judged among you : for he hath his judgment with God. For in like manner did also the prophets of old time. 12 But whosoever shall say in the spirit, give me moneys or any other things, ye shall not hearken unto him; but if he bid you give concerning others that are in need let no man judge him.

\section{CHAPTER XII}

Comp. Matt. x. 40-42. I ET everyone that cometh in the name of the Lord be received; and then after ye have tested him ye Jonah iv. 11 . shall know him ; for ye shall have understanding of right and left. 2 If he that cometh is a wayfarer, give him aid as much as ye are able; but he shall not abide with you save for two or three days if need be. 3 But if he be Acts xviii. $3 ; \mathbf{x x} .34$. willing to settle among you as being a craftsman let him labour and eat ; 4 but if he have no craft, provide according to your discretion that he shall not live idle amongst you as a Christian. 5 But if he will not do thus he is a trafficker in Christ : of such men beware.

\section{CHAPTER XIII}

BUT every prophet that is willing to settle among you

Matt. $x_{0} 10$. is worthy of his food. 2 In like manner a true teacher

Comp. Exod. xxii.

Lev. xxiii, Num. xviii.

Deut. xviii. is himself also worthy even as the labourer, of his food. 3 All the first-fruits then of the produce of wine fat and threshing floor, oxen and sheep, shalt thou take and give, even the first-fruits, unto the prophets, for they are your high priests; 4 But if ye have no prophet, give them unto the poor. 5 If thou makest a baking. of loaves, take the first-fruits and give according to the command- 
ment; and in like manner when thou openest a jar of wine or oil, take the first-fruits and give unto the prophets. 7 And of money and raiment and every possession take the first-fruits and give as seemeth good unto thee according to the commandment.

\title{
CHAPTER XIV
}

\begin{abstract}
$\mathrm{A}^{\mathrm{N}}$ ND on the Lord's day of the Lord assemble your- Rev. i. 10. selves together and break bread; and give thanks after having confessed also your transgressions, that ${ }^{*}$ your * or 'our' $i \mu \tilde{\omega} \nu$ or sacrifice may be pure. 2 And let not any man that is at variance with his fellow come together with you until they be reconciled, that your sacrifice be not polluted. 3 For this $†$ is that which was spoken of by the Lord: $†$ Sc. 'this sacrifice." In every place and time offer unto me a pure sacrifice, Mal. i. n. for I am a great King, saith the Lord; and My Name is wonderful among the Gentiles.
\end{abstract}

\section{CHAPTER XV}

GLECT therefore for yourselves $\ddagger$ bishops and deacons $\ddagger$ or overseers Cf. Acts worthy of the Lord, men that are meek, and not lovers of money, and true and approved. For they themselves also minister unto you the ministry of prophets and teachers, 2 therefore disregard them not; for it is they that are the honoured ones among you with the prophets and teachers. 3 And reprove one another, not in wrath but in peace, as ye have it in the Gospel; and to any man that wrongs his neighbour, let no one speak, neither let him hear aught from you until he repent. 4 And your prayers, and your alms, and all your actions, so perform ye them as ye have it in the Gospel of our Lord.

\section{CHAPTER XVI}

WATCH for your life. Let not your lamps be Luke xii. 35. quenched, and let not your loins be ungirded; but be ye ready, for ye know not the hour in which our Lord Matt. xxiv. 42. 
Mark xiii. 35. cometh. 2 And be frequently gathered together seeking the things which concern your souls; for the whole time of your faith shall not profit you except ye be

Matt. xxiv. 10-12. made perfect in the last season. 3 For in the last days the false prophets and the corrupters shall be multiplied; and the sheep shall be turned into wolves and love shall be turned into hatred; 4 for when lawlessness waxeth great, they shall hate and persecute and betray 2 Thess, ii. 3. one another; and then shall appear the deceiver of Mark xiii. 22. the world as the Son of God; and he shall work signs and wonders, and the earth shall be delivered into his

I Cor. iii: 13 . hands, and he shall work iniquities such as have never 1 Pet. iv. 12. been from everlasting. 5 Then shall the work of men Matt. xxiv. 27, 30, 31; come into the fire of trial, and many shall be offended, * 'Caused to stumble' and shall perish; but they that endure in their faith 1 Thess. iv. 16 shall be saved by the curse itself. 6 And then shall Deut. xxxiii. 2. appear the signs of the truth ; first the sign of a spreadZech, xiv. 5 . Matt. xxv. 3 I. ing out in heaven; next the sign of the sound of a trumpet; 7 and the third a resurrection of the dead; howbeit not of all, but as it was said, the Lord shall Rev. i. 7 . come and all His Saints with him; 8 then shall? the world see the Lord coming upon the clouds of heaven. 


\section{NO'TES}

Ch. I, v. i.-The parable of the Two Ways is familiar in early literature, classical as well as sacred. Prodicus in Xnophon's Memorabilia gives the well known story of the choice of Hercules. Plato's allegory of the "Chariot of the Soul" in the Phaedrus, contains the same idea. For the version of the Two Ways in the so-called Epistle of Barnabas, see Appendix A.

Ver. ii. For the negative form of the Golden Rule compare Tobit iv. I5, "What thou hatest do not to another." Taylor points out that this form is typically Jewish. We are reminded of the often quoted sentence in "Ecce Homo," "The old law began with Thou shalt not ; the new law with Thou shalt." Compare also Didache, chapter xvi, v. I.

Ver. 4. "Abstain," \&c. Apparently an interpolation. One would rather expect to find it in Chapter II, as a summary of the " second commandment" of the teaching.

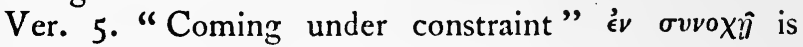
variously rendered " in distress" "under discipline" " in prison." Evidently some kind of punishment is meant. But there seems no authority for Prof. Rendel Harris's suggestion of a church prison or house of correction. The word for "prison" in Matthew v. 25, is $\phi v \lambda \alpha \kappa \eta$.

Ver. 6. "Let thine alms sweat" \&c. Many passages have been cited by Dr. Taylor and others in illustration of this passage. They appear to me rather to illustrate the Scriptural view of the dignity of labour than to throw light on the phrase taken with its context. To the general reader the intention would seem to be simply a correction of the large injunction, "Give to every one. that asketh of thee" (ver. 5), by prescribing judicious precaution against giving alms to the undeserving. 
"Keep thine alms warm in thine own hand until thou art sure of the right recipient." It "may be taken as anticipating the directions given in chapters xi. and xii., on the bestowal of alms on prophets and teachers. There is no doubt also a reference to the value of alms being given out of that which is acquired by sweat or labour.

Chap. iii. 1.-Dr. Taylor illustrates this by the Rabbinical saying, "Make a fence about the Law," i.e., to avoid breaking the law itself, avoid any action which might lead to such breaking. The Pharisaic precepts as to the observance of the Sabbath were a reductio ad absurdum of this principle. The tenth Commandment is itself of the nature of a "fence" against breaches of the sixth, seventh, eighth and ninth.

Ver. 5. "Be not a liar; for lying leads to theft." The inversion of the common view in this precept is remarkable. The form of lying specially denounced in the ninth commandment is in itself a form of theft : to bear false witness is to rob a man of his character:

* Othello, Act iii, Sc. 3 perhaps the worst kind of robbery.* "Who steals my purse steals trash; but whoso filches from me my good name robs me of that which not enriches him, and makes me poor indeed."

The passage is interesting as being quoted by Clement of Alexandria (about 200 A.D.), as Scripture. He writes, ". . . such an one is called a thief by Scripture ; at least it saith : Son, be not a liar, for lying leadeth unto theft," Strom. i. 20.

Chap. iv. 1.- "For where the Lordship is proclaimed there is the Lord." An apparent reference to our Lord's words : " $\mathrm{He}$ that receiveth you receiveth $\mathrm{Me}$; and he that receiveth $\mathrm{Me}$ receiveth $\mathrm{Him}$ that sent $\mathrm{Me}$ " (Matt. x. 40), and "Where two or three are gathered together in My name, there am I in the midst of them"

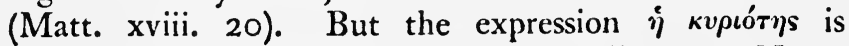
unique; and can here only mean " the Power or Name or Presence of the Lord." The sentence is paraphrased 
in the Apostolical Constitutions, "Where the teaching concerning God is, there God is present." Dr. Taylor also sees in it a reference to the favourite doctrine of the Rabbis, that those who are occupied with the "Thorah" or Law of the Lord have the Shekinah (the glory of the Divine Presence) amongst them. They used to quote in support of it Exodus xx. 24, and xxxiv. 5.

Ver. 6. Compare Testaments of the twelve Patriarchs (Zebulon viii). "As a man is pitiful towards his neighbour, so will the Lord be pitiful towards him."

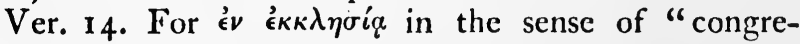
gation" (although without the article), compare I Cor. xi. 18, and xiv. 19, 28, 35. Some commentators would translate " in church " regarding the omission $\tau \hat{\eta}$ as evidence of "late workmanship." There is, however, no question as to its meaning in Corinthians.

Chap. v. 2.- The abrupt transition from abstract to concrete is noticeable. Dr. Taylor notes it as evidence of the early and Jewish origin of the Didache, and points out that the Apostolical Constitutions (a work of admittedly later date) soften the construction when quoting this passage, by inserting "for the doers of these things are," \&c. See also Barnabas, chap. xx. (Appendix A.)

Chap. vi., v. 2.- " The yoke of the Lord" clearly= the precepts of Christ which have been summarized in "the Way of Life," and are expressly styled "My yoke" by our Lord Himself (Matt. xi. 29, 30).

Chap. vii.-Baptism. The directions are of peculiar interest as being the earliest post-apostolic rules which we possess. The following points are noticeable :

I. The necessity of a preliminary course of instruction

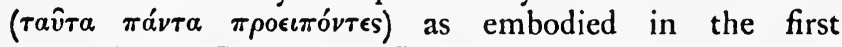
part of the Didache. In the Acts of the Apostles baptism appears to take place immediately on profession of faith in Christ (Acts ii. 41 ; viii. $36-38$; where note the omission and marginal reference in Revised Version; ix. 18 ; x. 47 ; and xvi. $30-33$ ). 
This preliminary instruction indicates, of course, that the great majority of the baptized were converts from heathenism; either adults or children who had attained "years of discretion."

2. The mode of baptizing. The rite is to be administered in "living," i.e., running water-i.e., either a stream or fountain. Cf. Lev. xiv. 50, the directions for purification of leprosy. This is to be the general practice. But it may be modified in special circumstances: (a) if "living" water is not accessible, other water, such as pools or cisterns, may be employed; and

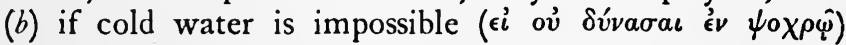
presumably on account of tender age or infirmity, warm water is permissible. Although in these directions there is no mention of infant baptism, this reference to warm water may reasonably be taken as a recognition of it; especially when it is remembered that baptism of infant proselytes to Judaism was an established practice. (Cf. Taylor ad loc. Lecture II.) (c) If neither "living" nor other water is available-and immersion unadvisablethen, almost in the words of our own Baptismal Office, it shall suffice to "pour water thrice upon the head in the name of the Father, Son and Holy Ghost."

The validity of the rite is not bound by the mode; the essential element of the sacrament being the use of water, not immersion in it. The symbolic character of the rite is recognized, and its spiritual significance; a marked contrast to the literal formalism of Jewish ritual, especially noticeable when we consider the early date of the document.

3. The absence of any restriction of the right to administer baptism. Nothing is said of any class of officials to which the prerogative is to be confined. In the Apostolical Constitutions the right of baptizing is restricted to bishops and presbyters. Hilary (Comm. ad. Eph. iv. I I, 12,) says that in early times "omnes docebant et omnes baptizabant," and there is no hint in the Acts of the Apostles of any restriction. St. Paul himself, for 
example, was baptized by Ananias, who does not appear to have been more than an ordinary disciple.

4. Fasting. With the directions for fasting as a preparation to be observed both by baptizer and baptized, we may compare the words of Justin Martyr (Apol. i. 6I. See Appendix II.).

It will be noticed that there is no hint of regeneration, or indeed of any doctrinal significance in the Didache. This may be taken as another mark of its early date.

5. The omission of all ceremonial detail. The signing of the cross on the forehead, the anointing with oil, the white robe, exorcism, the "Apage Satana," though introduced early into the ritual are not mentioned. It does not necessarily follow that none of them was used; we shall notice in discussing the Eucharist that there is no reference to points of ritual which must have been in use from its institution. Doubtless, however, the tendency in both sacraments was to elaboration of detail as time went on.

" Chap. viii. 1.-We read that the Jews fasted on Mondays and Thursdays, as being the days on which Moses ascended and descended from Mount Sinai. Christians are directed to fast on Wednesdays and * Fridays, the days of our Lord's betrayal and crucifixion. As Taylor points out, the distinction of days would be a conspicuous and efficient mark of separation between the Jews and Christian communities. I find no explanation of the expression "hypocrites" here as applied to the Jews. Hypocrisy was of course especially a Jewish sin. The use of the term is obviously borrowed from Matt. vi. 2, 5, 16; we may also compare Matt. xxiv. 5 I, and Luke xii. 46.

Ver. 2. The Lord's Prayer. It is worth while to compare the version in the Didache with those in St. Matthew and St. Luke. The variations are noted by different type.
* "Preparation," i.e., the day before the Sabbath, Cf. John xix. 31 . 
Matt. vi.

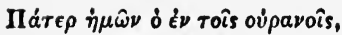

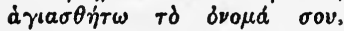

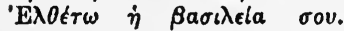
$\gamma \in \nu \eta \theta \dot{\eta} ; \omega$ Td $\theta \in \lambda \eta \mu d$ oov, $\dot{\omega} s$

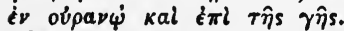

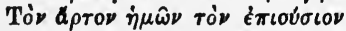

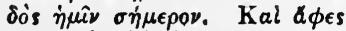
$\dot{\eta} \mu \hat{\nu} \nu$ Tà $\delta \phi \in i \lambda \eta \mu a \tau a ~ \dot{\eta} \mu \hat{\omega} \nu$,

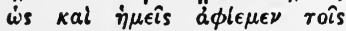
$\delta \phi \epsilon \iota \lambda \epsilon$ tals $\dot{\eta} \mu \hat{\omega} \nu$. Kal $\mu \grave{\eta}$

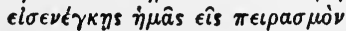

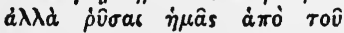

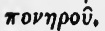

Didaché viii.

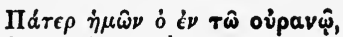
$\dot{a} \gamma \iota a \sigma \theta \dot{\eta} \tau \omega$ tò $\delta \nu 0 \mu \alpha \dot{\alpha} \sigma o v$.

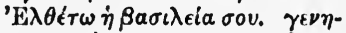

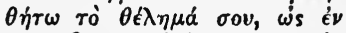

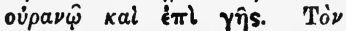

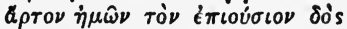

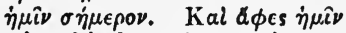

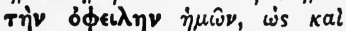
$\dot{\eta} \mu \epsilon \hat{i} \dot{a} \phi l \epsilon \mu \epsilon \nu$ rois $\delta \phi \epsilon \iota \lambda \epsilon \tau a \iota s$

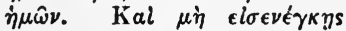

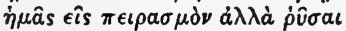

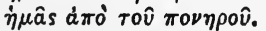

Luke xi.

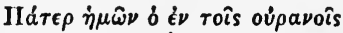

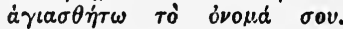

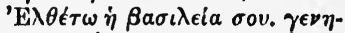

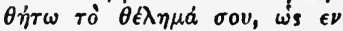

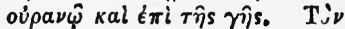

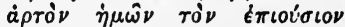

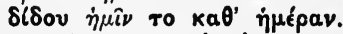

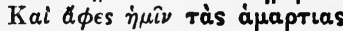
$\dot{\eta} \mu \omega \hat{\omega} \nu$, kal yàp aúrol ả $\phi \ell \epsilon \epsilon \nu$

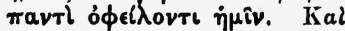

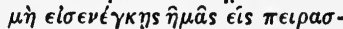

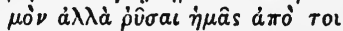

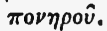

It will be seen at once that the differences between St. Matthew and the Didache are very slight. Other

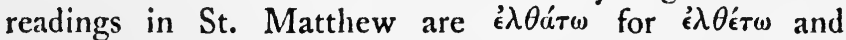
$\dot{\alpha} \phi \eta \kappa \alpha \mu \epsilon \nu$ for $\dot{\alpha} \phi i \epsilon \mu \epsilon \nu$. I have not printed the doxology, as it is now fully agreed that it formed no part of St. Matthew's original text. A noticeable omission, however, in the Didache is that of $\dot{\eta} \beta a \sigma ı \lambda \epsilon i a$. This expression is omitted in all the doxologies which occur in the treatise (ix. 2, 3, 4; x. 2, 4, 5). They were evidently used as appropriate conclusions to many prayers. "Thrice a day" is in accordance with Jewish practice. Cf. Psa. Iv. 18 ; Danish vi. 10 ; Acts iii. 1 ; x. 9 . This custom prevailed to later times; it is referred to and defended by Tertullian (de Ovat. and de Fejun. 10) and Clement of Alexandra (Stromata vii. 7), who adds " the Gnostic, however, prays throughout his whole life, endeavouring by prayer to have communion with God."

Chap. ix. 1.-The Eucharist, i.e., the Service of Thanksgiving, forms the subject of chapters ix., $x$. and xiv. This technical use of the abstract word ev́xapırтia is not found in the New Testament; but it was undoubtedly adopted at an early period. In the Didache the sacrament is regarded almost wholly from its Eucharistic or Thanksgiving side:- the prayers prescribed for use invariably opening with the words, "We thank Thee our Father" (or Holy Father), and one concluding, 
"Before all things we thank Thee that Thou art mighty ; Thine is the glory for ever" (x. 4). In chapter xiv. we find the direction to "break bread and give thanks" on the Lord's day. This aspect of the sacrament is certainly a continuation of the chief characteristic of the Passover which contained in its ritual a series of thanksgiving prayers or blessings, called Eulogiae; and it is worthy of notice that the expressions in Matt. xxvi. 26, 27, and Mark xiv, 22, 23, describing our Lord's actions at the institution of the supper contain the words

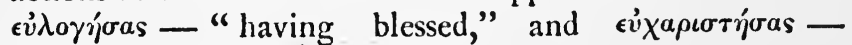
"having given thanks," St. Luke xxii. 17, 19, and St.

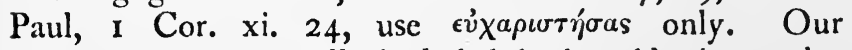
Lord's prayers naturally included both a blessing and a thanksgiving; we in our commemoration invoke the Divine blessing, and offer thanks to God for the spiritual gifts which the ordinance symbolizes. The words of Justin Martyr's Apology have often been quoted (Apol. i. 66), and will be found given in full in Appendix D. "This food (the sacramental bread and wine) is called

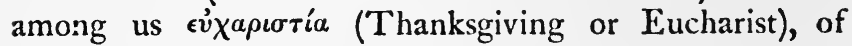
which no one is allowed to partake but the man who believes that the things which we teach are true."

Ver. 2. "The Holy Vine of David thy servant" [or son]. Taylor says, "The phrase is not found in any earlier writing." It is evidently a combination of the figure used by Christ of Himself as the True Vine (John Xv. I), and the expression " Root and oflspring of David," used in Rev. xxii. 16 . In the latter there is a reference to Isa. xi. I0, the "Root of Jesse." It is noted that Clement of Alexandria uses the phrase "the blood of the vine of David," evidently quoting from the Didache.

Ver. 4. The bread which is broken is regarded as an "acted parable" of the unity of the Church, the scattered members of which, dispersed throughout the world, are to be gathered into one kingdom, as the corn scattered abroad upon the hills is gathered into one bread. See also chap. $x .5$. 
Chap. x. I.—“After being filled." The expression shows that the Eucharist was celebrated together with the Agapé or "Love feast." The practice of combining the two ceremonies is another instance of Jewish ritual influencing the Christian Sacrament. The Passover was preceded by the Chagigah, with the intention, as Taylor points out in his quotation from the "Talmud," that the Passover might be eaten "after being filled." The abuses of this practice which we read of in I Cor. $\mathbf{x}$. and xi. rendered its abolition necessary. Justin Martyr's description of the celebration of the Eucharist in his time shows that it took place at the conclusion of Divine service on "the day which is called Sunday." "When our prayer is conclided, bread is brought and wine and water... and there is a distribution to each of the congregation and a sharing of the Eucharistic elements." (Apol. i. 67.)

Ver. 3. This prayer of thanksgiving, and in fact all the prayers prescribed in the Didache for use in the Eucharist, are evidently framed after the model of the Eulogiae of the Passover referred to in the previous note. In the Eulogiae thanks are offered for the fruits of the earth, and for the "good land given as an inheritance to our fathers." So in the Eucharistic prayers thanks are given for food and wine and for all the blessings of Creation; the sacramental elements being regarded not only as "outward and visible signs" of spiritual grace, but also as symbolizing the goodness of the Creator in giving to man the "kindly fruits of the earth."

Ver. 6. "Let grace come, and let this world pass away ;" a paraphrase of the clause of the Lord's prayer, "Thy kingdom come." Hosanna ( $\dot{\omega} s a ̉ v v a)$ Maranatha or Maran Atha.

The cry Hosanna (" save now," or "save we pray ") was used in connection with the Feast of Tabernacles. It occurs in Ps. cxviii. 25, "Help me now O Lord." Taylor points out that this verse is followed immediately by the words " Blessed be He that cometh in the Name 
of the Lord," and that this is the connecting link with the Syriac Maran atha, of which the meaning seems to be, "The Lord is at hand," or "The Lord cometh" : an expression of frequent occurrence in the epistles (I Cor. xvi. 22 ; Phil. iv. 5 ; I Thess. iv. 15 ; v. 23.), and evidently referred to in Rev. xxii. 12, 20.

Chap. xi. 9.- "A table," probably referring to the Agapé or Love-feast. The prophet might be suspected of appointing such a "table" or "feast" for his own indulgence, under the colour of a feast of charity to the poor.

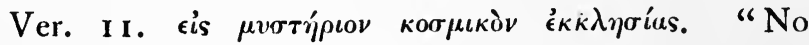
prophet approved and true, doing anything for an earthly, cosmic or worldly sign [or mystery] of the Church, but not teaching others to do as he docth, shall be judged by you, for his judgment is with God; for in such manner also did the prophets of old time."

This passage is the greatest difficulty in the Didache. Many explanations have been suggested : the most satisfactory is perhaps Dr. Taylor's. He illustrates the use

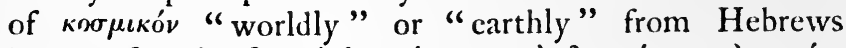

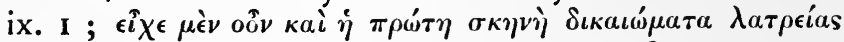

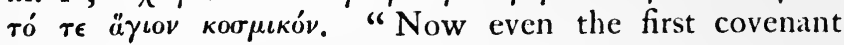
had ordinances of divine service, and its sanctuary a sanctuary of this world" [R.V.]. "As the cosmic sanctuary made with hands was a pattern of the heavenly, so a cosmic mystery is an idea depicted in the world of sense by emblematic actions or material objects."

The reference is to the method often used by the prophets of teaching by symbolic actions or objects. [Cf. I Kings xxii. I I ; Jer. i. I 3 ; Ezek. xxiv. 3; Hos. iii. I ; Zech. xi. Io, I 4 ; Acts xxi, I I.] But the Didache enters on the borderland of casuistry by laying down that it may be lawful to transgress the general law if the purpose be holy. "The priests in the temple profane the sabbath and are blameless" (Matt. xii. 5).

Dr. Taylor further illustrates the point by quoting Barnabas (Epistle chap. xii.) and Justin Martyr (Dial. c. 
Trypho), both of whom refer to the serpent of brass made by Moses for the healing of the people, and as a type of Christ, although he had himself delivered to Israel the commandment, "Ye shall have neither molten nor graven image," and "Cursed be the man that maketh a molten or graven image." Both Barnabas and Justin seem to refer to an oral Didache existing previous to any written treatise.

It will be observed that the Didache gives no example of the kind of actions in which a prophet might be allowed to infringe the law. But the instances quoted by Taylor from Barnabas and Justin Martyr may be regarded as bearing on the question of the use of art as an aid to Christian teaching.

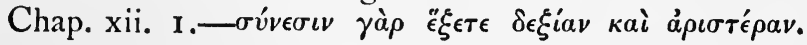
Compare the corresponding passage in the Apostolical Constitutions (vii. 28), "Ye are able to know the right hand from the left, and to discern false teachers from true." For the form of expression see also Jonah iv. II , of the people of Nineveh.

Chap. xiii. I, 2.-A postles (chap. xi. 3), prophets, teachers. These terms are often used not only in the Didache but also in the New Testament and other early Christian literature without any definite distinction. They are used indifferently of the same persons, according to the aspect of their work which at the moment is being considered. In the Didache the apostle is called a prophet (xi. 5, 6); but in xiii. 1, 2, the prophet and teacher are apparently distinct. But in Acts xiii. I; xiv. 4, 14 ; xv. 32 ; Gal. ii. 9 ; I Thess. i. I ; ii. 6 ; we read of Paul, Barnabas, Silas, and perhaps Timothy also, as "teachers," "apostles" and "prophets." We seem, however, to see in the early Church the rise of " teachers" who were a class by themselves, distinct from apostles and prophets. See I Cor. xii. 28, where the three classes are very definitely separated: "first, apostles ; secondly, prophets ; thirdly, teachers."

It appears from Rom. xii. 7, that "teaching" was 
one of the definite spiritual gifts of the early Church ; exercise of the gift being not confined to officials of the Church (Acts viii. 4 ; xi. 19; xviii. 26, 28 ; James iii. I), but open (as in the Jewish synagogue) to any whom the President might invite [Luke iv. 17 ; Acts xiii. 15; xvii. 2.]. It is laid down in the Apostolical Constitutions that "though a man be a layman, yet if he be experienced in the delivery of instruction and reverent in habit, he may teach ; for the Scripture saith 'they shall all be taught of God" " (viii. 31 ).

"Apostles." The term which at first was restricted to the twelve was afterwards extended to others. The qualification at first demanded-personal knowledge of the Lord during his ministry (Acts i. 21)-was not rigidly adhered to, for we find Timothy and Silas described by St. Paul as apostles together with himself (1 Thess. i. I ; ii. 6). That the extension of the term may not at first have been generally approved is suggested by St. Paul's indignant question in I Cor. ix. I ; and perhaps we should recognize that when the title had become generally extended, a distinction was made between the original apostolate and those who were simply missionaries-men in fact as the term implies "sent forth." At all events it seems clear that the term was generally used at the period of the Didache, and that the Church needed to be shown how to discern the true Evangelist or missionary from the many false who sought to impose themselves on believers.

"Prophets." That it is clear from ver. 4 of chap. xiii, that one of the prophetic functions was that of almoner. If no prophet was present the alms were to be given directly to the poor. The essential difference between the "prophet," properly so called and the "apostle" and the "teacher" was apparently his gift of speaking "in the Spirit" ('€v $\pi v \in v ́ \mu a \tau \iota)$, in fact "prophesying" as in I Samuel x. 10, and elsewhere. This gift did not, however, as in the case of Saul, prove him to be a true prophet; "Not every one," says the 
Didache (xi. 8), "that speaketh in the Spirit is a prophet ; but only if he have the ways of the Lord." If a prophet took money for himself, or ordered a lovefeast or table for his own benefit, he would not have the ways of the Lord, and would be thereby proved a false prophet. Generally speaking the prophets were held in considerable honour (even in their own country, though for the most part they were itinerant missionaries). We see, for example, in chap. x. 7 , that they were allowed to give thanks in public after their own manner, and were not restricted to prescribed forms of prayer. All the first-fruits are to be given to them "for they are your chief priests" (xiii. 3). In this respect at least they held the same position towards the Christian Church as the priesthood in the Jewish Church, in having no personal means of livelihood, but depending for support on the offerings of the community.

Chap. xiv. 1._-"The Lord's day of the Lord." кирьакүे кирíov. Dominica Domini. The title is peculiar. The day is always-with one exception-spoken of in the New Testament as the "first day of the week," (John xx. I, I9; Acts xx. 7 ; I Cor. xvi. 2.). The exception is Rev. I. IO, "I was in the Spirit on the Lord's Day "; which indicates a later date than would ordinarily be assigned to the Apocalypse. But the double expression here used is apparently unique. In the corresponding passage as the Apostolical Constitutions the words are " the day of the resurrection of the Lord, that is, the Lord's Day." This fuller phrase suggests the doubt whether the tautology of the Didache may not be due to some mutilation of the text, by which some words have dropped out. Dr. Taylor supposes the formula in the Didache to have been constructed with the definite purpose of contrasting the new holy day, with the old Sabbath. Instead of a "Sabbath of the Lord" Christians were to celebrate a "Lord's Day of the Lord."

In any case this passage in the Didache is valuable, as some of the earliest evidence extant of the observance by 
Christians of the Lord's Day. The testimony of Pliny in his famous letter to Trajan, and of Ignatius in his Epistles would come very near it in point of time : and next to him Justin Martyr in his first Apology. Pliny speaks of Christian services taking place "stato die" and, (if we may accept him) Ignatius (Ep. ad Magnes 9.) describes the converts from Judaism as " no longer Sabba-

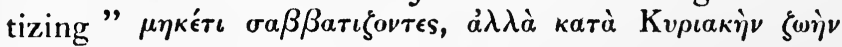

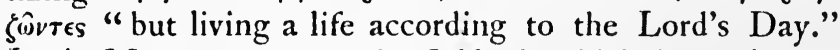
Justin Martyr contrasts the Sabbath which is no longer to be observed by Christians with the Lord's Day on which God began the work of creation, and the Saviour rose from the dead. It is worth while to notice in passing, that the earliest reference to cessation from weekly labours on the Lord's Day is in 'Tertullian, who died about 216 A.D. "Quo die" he says "omni anxietatis habitu et officio carere debemus, differentes etiam negotia ne quem diabolo locum demus" - "on which day it is our duty to free ourselves from all worldly care and trouble, even postponing business, lest we should give place to the devil."

Ver. 1, 2. "That our [or your] sacrifice be pure not defiled." The Eucharistic Sacrifice clearly means the " sacrifice of praise and thanksgiving :" also the " reasonable holy and lively sacrifice" of the worshippers, in soul and in body. It is not possible to read into the text any reference to the "sacrifice of the mass," in which the sacrament is regarded as a repetition of Christ's Sacrifice of Himself on Calvary.

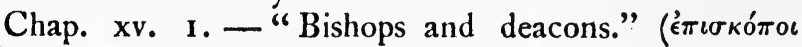

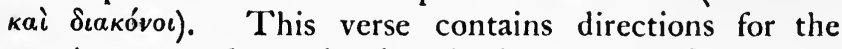
appointment of the local officials of the Church as distinct from the itinerant ministers described in Chapters $\mathrm{xi}$, xii and xiii. From the absence of the word $\pi \rho \epsilon \sigma$. $\beta$ ví $\epsilon$ os (elder or presbyter) from our treatise it is reasonable to infer with Bishop Lightfoot that at the date of the Didache "Bishop" and "Elder" were identical in meaning; the episcopal office not having yet been

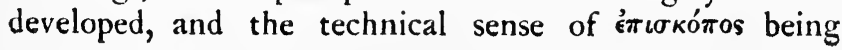


therefore unknown. The theories of Hatch and Harnack, ingenious though they are, do not carry conviction and indeed are to some extent mutually destructive.

What we may take as definitely established (unless like these critics we reject the Pastoral Epistles and relegate much if not all of the Acts to the 2nd century) is that the existence of Presbyters in the Church at Jerusalem is recognised from the first (Acts xi, 30 ; xv. 4, 6, 23.); that the ordination of Presbyters in Gentile Churches took place as a matter of course (Acts xiv. 23, xx. 17,); while the Pastoral Epistles are full of the work and qualifications of the Order. No record is given of the institution of the order but it is generally admitted to have been modelled on Jewish precedent. There is much probability that it began in the Christian Church with the appointment of the Seventy by our Lord (Luke X. I).

As to the Episcopate, the negative evidence of the Acts and the Pastoral Epistles shows that the Episcopal Order did not assume definite existence so long as the Apostolate remained.

The germ of the order may be seen in the presidency of S. James over the Council at Jerusalem (Acts xv); in the authority entrusted to Timothy and Titus as delegates of S. Paul ; possibly also in the recognition of the "Angels" of the Seven Churches [Rev. ii, iii.] Bishop Barry in his Annotated Edition of the Church Service says "There is ample evidence that from the early years of the 2nd Century onwards the Episcopate as the highest Order in the Ministry received general recognition not only from the Church but also from the heretical sects which seceded from it." This is however open to question.

The Ignatian Epistles, even if genuine, describe the bishop rather as the minister of a congregation than the ruler of what we understand by a diocese ; and in Irenæus (at the close of the second century) the bishop though over the presbyters is (as Bishop Lightfoot says) "still regarded as one of them " and is as often called "presbyter" as "bishop." He is in fact "primus inter pares." 
But we may take it that with the growth of the Church and of her need of organized government, the order of the Episcopate gradually acquired definite shape and authority, proceeding from a local, and quasi-parochial position to the higher presidential responsibilities which the term connotes in later times.

The office of stákovos is clearly traceable to the appointment of the Seven in Acts vi. It is true that they are nowhere expressly called deacons; but in the account of their appointment we find both scakovia and

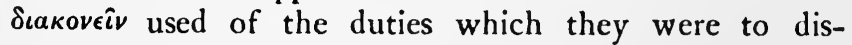
charge, namely the "daily ministration" and the "serving" or "ministering to tables." The original purpose of the diaconate was the care and distribution of the funds contributed by the rich members for the relief of the poor. The work of the deacons, therefore, in some degree coincided with what as we have seen in chapter xiii. of the Didache, was a function of the prophets. They were public almoners; and this duty is no doubt included in the expression " $\lambda \epsilon \iota \tau o v \rho \gamma o v \sigma \iota$

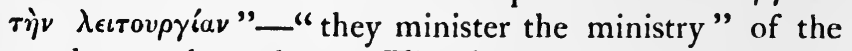
prophets and teachers. The deacons mentioned by St. Paul (Phil. i. I ; I. Tim. iii. 8) are generally regarded as holding the same office; and this view is strengthened

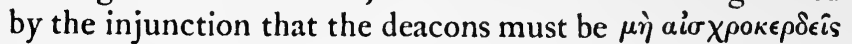
" not greedy of filthy lucre." Their functions naturally became extended as the organization of the Church developed. Justin Martyr speaks of them as distributing the bread and wine in the Eucharist. In the Apostolical Constitutions, when the bishop's authority has become established, the deacons appear as his administrators, charged with the duty of visiting the poor, enquiring into their circumstances, and making report thereon to the bishop. With the "presbyter-bishops" they are associated, not only in the case of the poor, and the collection and disbursement of alms, but also in the public worship of the Church.

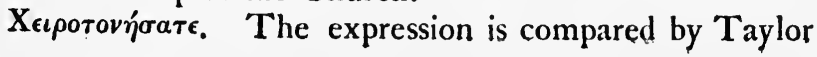


to that in Acts vi. 3. The community make the selection of candidates; the apostles ordain and

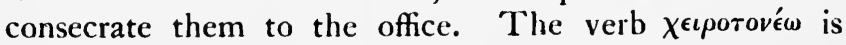
clearly used here in the New Testament sense of "to elect." In later times it meant " to ordain."

Chap. xvi.-The treatise is appropriately concluded by an exhortation to watchfulness and preparation for the Second Advent. It closely resembles our Lord's warnings recorded by the Synoptists; and there is a striking parallel in v. 4 to St. Paul's teaching in II. Thess. ii. 3-12, on the coming of Antichrist. The expressions in I. John iv. 3 and II. John 7 should also be compared with it.

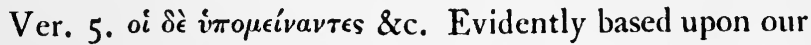
Lord's words recorded in Matt. xxiv. 13, and Mark xiii.

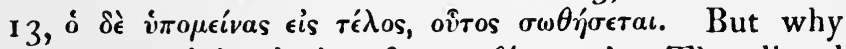

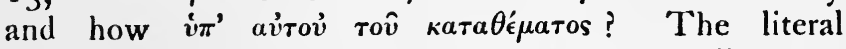
meaning is "by the accursed thing itself" rather than "by the very curse." The simplest explanation of the paradox, though not apparently noticed by the commentators, would seem to be afforded by the context - "the furnace" or "fire of trial "-which, though a destruction to the ungodly, will, by its refining and purifying power, be the salvation of the faithful. There may be also a reference to Gal. iii. 13, "Christ being made a curse for us," though the words there are karápa

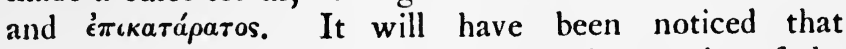
there is no mention made throughout the treatise of the Cross of Christ. May not this, however, be a metaphorical allusion to it ?- "Saved by the accursed thing," i.e., by the Cross or the Crucifixion of the Lord. (Were

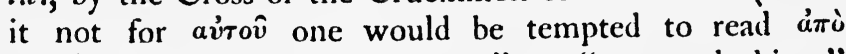
for $\dot{v} \pi \grave{c}$, "saved from the curse" or "accursed thing," i.e., the doom that awaits the wicked.

Ver. 6. The three signs of the Second Advent : First, the sign of an outspreading in heaven; next, the sign of the voice of a trumpet; and the third, a resurrection of the dead." The second and third signs present 
no difficulty; they are identical with the teaching of I. Cor. xv. and I. Thess. iv., and rest on the authority of our Lord's words (Matt. xxiv. 31, Luke xx. 35) ; but

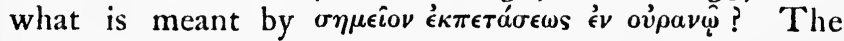
explanation adopted by Dr. Taylor is that suggested by Archdeacon Edwin Palmer, "a spreading of the hands transversely to the body so as to form a cross." Barnabas, in chap. xii. of his epistle, quotes several prefigurements of the cross in the Old Testament, e.g., Moses stretching out his hands to enable Israel to conquer Amalek; the brazen serpent set upon a pole; the words of Isaiah, "All day long have I spread forth my hands," \&c. Justin Martyr also, and the Sibylline Oracles (fully dealt with by Prof. Rendel Harris in his Teaching of the Twelve Apostles and the Sibylline Books) illustrate the same idea, and regard the "sign of the Son of Man in Heaven " as a vision of Christ crucified. These, and other suggestions and illustrations, are remarkable for their ingenuity, and for the labour which has been bestowed upon them; but it is questionable whether after all it is not more consonant with the early simplicity of our treatise to avoid all explanations that are mystical and fantastic, and to regard the expression as simply resting on the words of our Lord in Matt. xxiv. 27, "As the lightning cometh forth from the east, and is seen even unto the west, so shall be the coming (mapovoía) of the Son of Man :" or as in Luke xvii. 24, "As the lightning when it lighteneth out of the one part under the heaven shineth unto the other part under heaven, so shall the Son of Man be in His day." The "sign of the Son of Man" (mentioned only in St. Matthew) may well be left without attempt at explanation. The best comment is that of Mr. Carr in the Cambridge Bible, "What this [sign] shall be it is vain to conjecture; but when it appears its import will be instantly recognized by the faithful."

The omission of the phrase from the other Synoptist points to the possibility of its being simply a periphrasis 


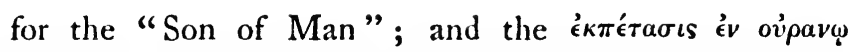
may be a literal misunderstanding of Christ's metaphorical description of the suddenness and all-pervading nature of His $\pi$ apovoía. 


\section{APPENDIX A.}

The “Two Ways" in the Epistle of Barnabas.

Chap. xviii. Now let us pass on to other knowledge and teaching. There are two ways of teaching and of authority, the way of Light and the way of Darkness, and there is much difference between the two ways. For over the one there are appointed light-bringing angels of God, but over the other angels of Satan. And the former [God] is the Lord from everlasting to everlasting; but the latter [Satan] is the prince of the time that now is of lawlessness.

Chap. xix. The way of Light then is this, if a man, being desirous to take his way to the place appointed, be zealous in his deeds. The knowledge then which has been given to us that we may walk therein is after this manner. Thou shalt love Him that created thee, thou shalt fear Him that fashioned thee, thou shalt glorify Him that redeemed thee from death : thou shalt be single in heart and rich in spirit. Thou shalt not be joined with them that walk in the way of death, thou shalt hate all that is not pleasing to God, thou shalt hate all hypocrisy, thou shalt in no wise forsake the commandments of the Lord. Thou shalt not uplift thyself but shalt be humble-minded in all things. Thou shalt not take glory to thyself, thou shalt not take evil counsel against thy neighbour; thou shalt not give insolence to thy soul. Thou shalt not commit adultery, thou shalt not commit fornication, thou shalt not corrupt children. The word of God shall in no wise go forth from thee where any are unclean. Thou shalt not respect any person in rebuking for transgression. Thou shalt be meek, thou shalt be peaceable, thou shalt be in fear of the words which thou hast heard. Thou shalt not be mindful of evil against thy brother or bear malice. 
* $\gamma \epsilon \nu \nu \eta \theta \epsilon$

Thou shalt not waver in spirit whether it shall be yea or no. Thou shalt not take the name of the Lord in vain. Thou shalt love thy neighbour more than thy life. Thou shalt not destroy a child by abortion, neither again shalt thou slay it when born.* Thou shalt not take away thy hand from thy son or from thy daughter, but from their youth up thou shalt teach them the fear of God. Thou shalt not be covetous of thy neighbour's goods; thou shalt not be avaricious. Thou shalt not be joined in thy soul with the lofty, but with the lowly and just shalt thou converse, The operations [of God] that befall thee, accept as good, knowing that without God nothing cometh to pass. Thou shalt not be double-minded nor double-tongued; for to be double-tongued is a snare of death. Thou shalt be subject to thy masters as to an image of God in shamefastness and fear. Thou shalt not lay commands in bitterness upon thy bondman or maidservant who hope in the same God, lest at any time thou cease to fear Him who is God over both : since He came not to call men according to outward appearance but to those whom the Spirit made ready for Him. Thou shalt share in all things with thy neighbour, and shalt not call anything thine own; for if ye be sharers in that which is imperishable, how much more in the things which are perishable? Thou shalt not be of forward speech ; for the mouth is a snare of death. As much as thou art able, thou shalt be pure for thy soul's sake. Be not one that stretcheth forth his hands to receive, but withholdeth them for giving. Thou shalt love as the apple of thine eye every one that speaketh unto thee the word of the Lord. Night and day be mindful of the day of judgment, and every day shalt thou seek out the faces of the or 'by the Word.' saints, either labouring by word of mouth $t$ and going forth to exhortation and meditating how to save a soul by the word, or by thy hands shalt thou work for the redemption or atonement of thy sins. Thou shalt not hesitate to give, neither when thou givest shalt thou 
murmur* but thou shalt know who is the fair recom-* or grudge. penser of the reward. Thou shalt keep what thou hast received, neither adding thereto nor taking away. Thou shalt utterly hate the wicked man.t 'Thou shalt judge for 'the cril one' as righteously. Thou shalt not make division, but thou shalt reconcile and bring together them that are at strife. Thou shalt make confession over thy sins; thou shalt (possibly) in the Lord's Praver, and as in Ep. Barnabas ii. 10. not come to prayer $\ddagger$ with an evil conscience. 'This is $\ddagger$ or 'place of prayer.' the Way of Light.

Chap. xx. But the Way of Darkness is crooked and full of cursing. $\$$ For it is the way of eternal death with $\S$ or ' of the Black punishment, wherein are the things that destroy the One.' soul ; idolatry, insolence, haughtiness of power, hypocrisy, duplicity, adultery, murder, plundering, arrogance, transgression, guile, malice, stubbornness, sorcery, witchcraft, avarice, defiance of God. Persecutors of the good, hating truth, loving falsehoods, not acknowledging the reward of righteousness, not cleaving to that which is good, nor to righteous judgment; not regarding the widow and orphan, watchful not toward the fear of God but toward evil ; from whom meekness and patience are far removed; loving vain things, seeking after recompense ; not pitying the poor, not sorrowing with the sorrow-laden, ready to speak evil, not acknowledging their Maker, murderers of children, destroyers of the image of God, turning away from the needy, and grieving the afflicted, advocates of the rich, lawless judges of the poor, wholly given to sin.

\section{APPENDIX B.}

Letter of Pliny to the Emperor Trajan, 103 a.d.

I make it a rule, Sire, to refer to you all matters on which I am in uncertainty. For who is better able either to guide my perplexity or to instruct my ignorance? I have never been present at any judicial examination of Christians; consequently I have no knowledge of the direction or degree of punishment or inquiry which custom permits. It has also greatly embarrassed me to 
decide whether there should be any distinction made between different ages, or the same treatment for children and adults; whether a chance of repentance should be given, or no benefit allowed to him who has once been a Christian if he afterwards recants; whether the mere profession of Christianity without its crimes is to be punished, or only the crimes which are associated with it. Meanwhile in the cases of those who have from time to time been reported to me as Christians I have adopted the following course. I have demanded of them whether they really were Christians; and if they admitted it I repeated the question a second and a third time, with the threat of the capital penalty, and if they persisted I ordered them to be executed. For I could not doubt that whatever might be the substance of their confession, at least their obstinacy and unyielding tenacity merited punishment. There have been other victims of this folly whom, as they were Roman citizens, I have noted to be sent to Rome.

After this, as usually happens, accusations came in more plentifully owing to the mere fact of the matter being made public, and various phases of the crime were revealed. An anonymous list was posted up containing many names. There were some who denied that they were or ever had been Christians; who recited at my dictation a form of prayer to the gods, and paid adoration with incense and wine to your image, which I had ordered to be brought for that purpose together with figures of the gods, and who, moreover, cursed Christ. None of these things it is said the real Christian can be made to do: and I accordingly thought it right to set these persons at liberty.

Others who had been named by an informer first said they were Christians and then denied it; they had been so, they said, but had renounced it-some three years ago, some many years, a few of them even twenty years ago. They all worshipped your image and the figures ot the gods, and cursed Christ. They declared, however, 
that the sum of their crime or folly was no more than this : that they had been accustomed on a fixed day to assemble before sunrise, and to repeat in turn, with one another, a form of words addressed to Christ as to a god, and to bind themselves by a solemn oath, not to any criminal purpose, but against the commission of theft, robbery or adultery; against breaking faith or repudiating a trust. That after this had been done they had been wont to separate, and afterwards meet again for the purpose of taking a meal, a meal, however, quite ordinary and harmless; but they had given up even this after my edict, in which I had, according to your instructions, forbidden secret societies or political clubs. I thought it, however, the more necessary, to try further to elicit the truth by examining with torture two maidservants, who were called "deaconesses." But I could discover nothing else than an absurd and extravagant superstition; and so I adjourned the proceedings, in order that I might at once consult you. For indeed the matter seemed to me to deserve such consultation, especially on account of the large numbers involved. Many of every age and rank, both men and women are and will be imperilled. It is not only cities but villages and country districts as well that have become infected with this superstition; however, it seems that it can be arrested and cured. At any rate it is a fact that temples which had: been almost abandoned are beginning to be frequented, and religious festivals which had long been unobserved are now being resumed; while sacrificial victims now find a ready sale, though only a short while ago it was a rare thing to find a purchaser. From all this one may easily infer how great a number may be reclaimed from error if only the opportunity is given for repentance.

Trajan's Reply to Pliny.

You have done quite right, my dear Secundus, in discriminating the cases of the persons who have been 
reported to you as Christians. For it is impossible to lay down any general rule which can assume a definite shape. The Cliristians must not be sought out; but if they are reported and convicted they must be punished : with this limitation, however, that any one who declares that he is not a Christian, and proves his declaration by fact-that is by worshipping our gods-shall obtain pardon on the ground of repentance, even though he may have been suspected in past time. The posting of anonymous accusations cannot be allowed to form parts of the case against any one. That would be a dangerous precedent and unsuited to the age we live in.

\section{APPENDIX C.}

GREEK AND LATIN FATHERS QUOTED OR REFERRED TO IN THE TEXT.

Clement of Rome.-Author of an Epistle to the Corinthians, included in the Codex Alexandrinus, and in the volume containing the Didache discovered by Bryennios; date about 95 A.D. He may possibly be the Clement mentioned in Phil. iv. 3. His name is given by Iraenæus in the list of early Bishops of Rome.

Ignatius.-Bishop of Antioch, probably 95-1 16 A.D. Seven Epistles attributed to him have been the subject of much controversy. He suffered martyrdom at Rome under Trajan.

Justin MarTyr.-A Greek philosopher, born about IOO A.D. He was converted to Christianity in Palestine, and went to Ephesus after the rebellion under Bar-cochba in 132 A.D. At Ephesus he held his celebrated "Dialogue with Trypho," in which he shows that Jesus is the Messiah of the Old Testament. At Rome he wrote his two "Apologies" in defence of Christianity; the first to Antoninus Pius, and the second to Marcus Aurelius. He was martyred in A.D. 164. See Appendix D.

Iren mus. - A disciple of Polycarp, Bishop of Sinyrna. Born in Asia Minor in the second century, and first 


\section{THE TEACHING OF THE TWELVE APOSTLES}

mentioned as a presbyter of Lyons, during the great persecution, A.D. 177, under Marcus Aurelius. Part of his great work, the "Refutation of the Gnostics," has been preserved (a Latin version of five books). He suffered martyrdom under Septimius Severus in 202 A.D. See Appendix D.

Clement of Alexandria.-A disciple of Pantænus, the Christian Stoic. He succeeded him in the Catechetical School at Alexandria, A.D. I 88 . He remained there until A.D. 202, when the edict of Severus against the Christians drove him to Cappadocia. The date and place of his death are unknown. His "Stromata" or Miscellanies are valuable and interesting, containing facts and quotations not found elsewhere. His other works are "Pædagogus" and "Protrepticon." In all he aims at showing the influence of the Divine Logos through all history in the minds of men.

Tertullian.-The first Latin Father. He was born at Carthage, and wrote during the reigns of Severus and Caracalla. He was eloquent, impetuous, fanatical ; an oppoinent of the Gnostics, and, in later life, a Montanist. He died about 220 A.D.

\section{EARLY ROMAN EMPERORS AFTER AUGUSTUS.}

Tiberius

Caligula

Claudius

Nero

Galba

Otho

Vitellius

Vespasian

Titus

Domitian
A.D.

I3 Nerva

37 Trajan

4 I Hadrian

54 Antoninus Pius

68 Marcus Aurelius

69 Commodus

69 Pertinax

69 Julianus

79 Septimius Severus

8I Caracalla
A.D.

96 98

I 7

138

161

180

192

I 93

193

2 II 


\section{APPENDIX D.}

Justin Martyr (Apology i. 6I).-Baptism and the EUCHARIST.

Chap. 6I. "How we dedicated ourselves to God, being created anew through Christ, I will explain, lest if I omit this I shall seem to be deceiving in my explanation. All who are persuaded and believe that the things which are taught and affirmed by us are true, and who promise to be able to live accordingly, are taught to pray and entreat God with fasting to grant them forgiveness of their former sins; and we pray and fast with them. Then we bring them to where there is water; and after the same manner as we were ourselves also regenerated they are regenerated; for in the name of God the Father and Lord of all things, and of our Saviour Jesus Christ, and of the Holy Ghost, they then receive the washing of water; for indeed Christ also said, Except ye be born again ye shall not enter into the kingdom of heaven. . . .

"And we have received from the Apostles the following reason for so doing: Since we were ignorant of our first birth . . . and were brought up in evil customs and wicked training, in order that we might not remain the children of necessity and ignorance, but of choice and knowledge; and that we might obtain in the water remission of the sins that we had formerly committed, there is spoken over him who chooses the new birth and who repents of his sins the Name of God the Father and Lord of all things; and calling Him by this name alone we bring this person to be washed to the laver. ... Now this washing is called Illumination,* because they who learn the meaning of these things are enlightened in their mind. And in the name of Jesus Christ who was crucified under Pontius Pilate, and in the name of the Holy Ghost who by the prophets foretold all these things about Jesus, does he who is enlightened receive his washing." 
Chap. 65. "But after thus washing him who has professed and given his assent, we bring him to those who are called brethren, where they are gathered together, to offer prayers in common both for ourselves and for the person who has received illumination, and for all others in all places, with all our hearts, that we might be vouchsafed now we have learnt the truth, by our deeds also to be found good citizens and keepers of the Commandments that we may obtain eternal salvation. We salute one another with a kiss when we have concluded the prayers; then is brought to the president ${ }^{*}{ }^{*} \tau \hat{\varphi} \pi \rho \circ \sigma \sigma \tau \hat{\omega} \tau \iota$ of the brethren bread and a cup of mingled water and wine, which he receives, and offers up praise and glory to the Father of all things through the name of His Son and of the Holy Ghost ; and he makes a thanksgiving $\dagger$ at $+\epsilon \dot{x} x a \rho$ oriav length for the bestowal of these gifts by Him. When he has concluded the prayers and thanksgiving, all the people present give assent, saying Amen. ['The word Amen in Hebrew signifies So be it.] And when the

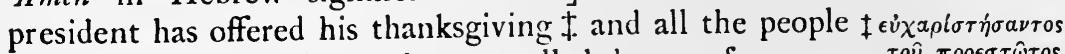

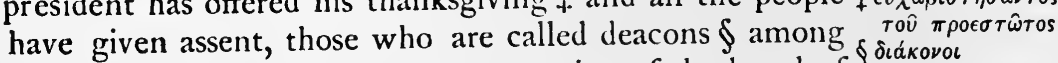
us give to each of those present a portion of the bread of $\$$ orákovor thanksgiving and of the wine and water; and they carry [some] away to those who are not present.

Chap. 66. And this food is called among us a Thanksgiving or Eucharist, of which no one is allowed to partake save him who believes the truth of our doctrines, and who has been washed in baptism for the remission of sins and for regeneration, and who lives even as Christ directed us. For we do not receive these [elements] as ordinary food or ordinary drink; but as by the Word of God Jesus Christ our Saviour was made flesh, and took upon Him flesh and blood for our salvation; even so also the food which has been blessed in prayer by that same Word of His, and from which our flesh and blood by assimilation derive nourishment, we are taught to believe to be both the flesh and blood of that Jesus who was made flesh. For the Apostles, in the memoirs they 
composed which are called Gospels, have left it on record that they were commanded to do after this manner: Jesus, they say, took bread, and when $\mathrm{He}$ had given thanks $\mathrm{He}$ said, 'Do this for a remembrance of $\mathrm{Me}$; this is My Body.' Likewise also he took the cup, and when He had given thanks He said, 'This is My Blood,' and gave it to them alone." ...

Chap. 67. "But we after these things do continually remind one another of them; and those of us who have the means, assist all who are in need; and we are always together; and in all our oblations we bless the Maker of all things, through His Son Jesus Christ and through the

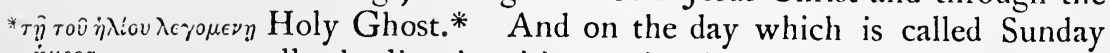
$\dot{\eta} \mu \epsilon \rho q$ all who live in cities or in the country gather together into one place, where the memoirs of the apostles or the writings of the prophets are read as long as we have time. Then, when the reader has ended, the president instructs verbally, and exhorts us to the imitation of these excellent things. Then we all rise up together and pray; and, as I said before, when we have ended our prayer, bread is brought and wine and water; and the president in like manner offers up prayers and thanksgiving to the best of his power; and the people give assent by saying, Amen. And there is a distribution to each, and every one partakes of the Eucharistic elements; and to those who are not present they are sent by the hands of the deacons. And such as are wealthy, and desire so to do, give what they will, each man as he is disposed. And that which is collected is given into the president's hands; and he assists the orphans and widows, and all who through sickness or any other cause are in need : and to those who are in bonds, and to strangers sojourning among us, and in a word to all that are in need he is a protector. But Sunday is the day on which we all hold our common assembly, because it is the first day on which God, when He transformed darkness and matter, created the world, and Jesus Christ our Saviour on the same day rose from the dead; for on the day before Saturn's day $\mathrm{He}$ was 
crucified, and on the day following it, which is Sunday, $\mathrm{He}$ showed Himself to $\mathrm{His}$ apostles and disciples, and taught them those things which we have delivered to you also for your consideration."

\section{Dialogue with Trypho.}

Chap. 4I. "God speaks thus by Malachi of the sacrifices then offered by the Jews, of whom Trypho is one : 'I have no pleasure in you saith the Lord, neither will I accept your offerings at your hands; for from the rising of the sun even unto the going down of the same My name hath been glorified among the Gentiles; and in every place incense is offered unto $\mathrm{My}$ name, and a pure offering, for $\mathrm{My}$ name is great among the heathen saith the Lord, but ye profane it.' Now with regard to those sacrifices which are offered to Him in every place by us Gentiles, that is of the Eucharistic bread and likewise of the Eucharistic cup, $\mathrm{He}$ then foretold that we, the Gentiles, of whom Justin is one, should glorify His name, but that you should profane it."

IRENAEUS also comments on Malachi i. IO-I2, as being fulfilled in the Eucharist. He lays the same stress that we find in the Didache, on the fact that the offering in the Eucharist is of the fruits of the earth. In his fourth book, chap. I7, he says: "When Christ was giving directions to $\mathrm{His}$ disciples and bidding them offer to God the first-fruits of His creatures, not as though God needed anything but to show that they were themselves not unfruitful or unthankful, $\mathrm{He}$ took of $\mathrm{His}$ creature Bread, and gave thanks, saying, "This is $\mathrm{My}$ Body ;' and in like manner the Cup, which also belongs to the creation of this our world, declaring it to be His Blood : and thus He taught us the new oblation of the New Covenant or Testament, which oblation the Church receiving from the apostles, offers throughout the world to God, who gives us food, the first-fruits of $\mathrm{His}$ gifts in the New Covenant, concerning which covenant 
Malachi in the twelve prophetic books thus prophesied, 'In every place incense shall be offered,' \&c. 'Therefore the Church's oblation which the Lord taught us should be offered throughout the world, is accounted a pure sacrifice before God, and is accepted by Him ; not that He needs any sacrifice from us, but because he who offers it is himself honoured in his offering when his gift is accepted."

In a further passage the view of the Eucharist as a thanksgiving for creation is even more clearly expressed. $\mathrm{He}$ is speaking of the Gnostics who deny that God is the Creator, and asks "How can these men consistently declare (quo modo constabit eis) that this Bread over which thanksgiving is offered is their Lord's Body, and that the Cup is the cup of His Blood, if they refuse to admit that $\mathrm{He}$ is Himself the Son of the Creator of the world-that is to say that He is the Word [of God] whereby the tree bears fruit, and the waters flow, and 'the earth brings forth first the blade, then the ear, after that the full corn in the ear'?"

The only 'sacrifice' in the Eucharist known to the Church of the Apostolic and sub-Apostolic age is that which is described in such passages as these, and in the portion of the Didache which they illustrate. "It may be said generally that for 200 years (i.e., until Cyprian) the Church never spoke of a sacrifice in the Eucharist except as an offering to God of the fruits of the earth, or as an offering of prayer and praisc. In these senses the fathers before Cyprian call it habitually an oblation or sacrifice, but in no other." [Cf. Norris, "Rudiments of Theology," and Bishop Harold Browne on the "Thirtyfirst Article."]

IGNATIUS.-On the threefold order of the ministry. The following extract from his "Letter to the Trallians" may be considered genuine, though the whole question of the authenticity of the seven epistles is still sub judice.

That he wrote epistles-six to certain churches and one to Polycarp-during his journey from Antioch to 
Rome is accepted as fact ; but the first documents have been subjected to such vigorous "editing" that it is doubtful how much of the original text survives. There is a Syriac version, and two Greek recensions, a shorter and a longer: the longer is by a later hand.

Ep. AD Trallianos, Chap. ii. "For when you submit yourselves to your Bishop* as to Jesus Christ, you * tiokomos $^{*}$ appear to me to be living not according to man but according to Jesus Christ who died for us, in order that by believing in His death ye might escape from death. It is necessary therefore, even as is your custom, do nothing without your Bishop. But submit yourselves

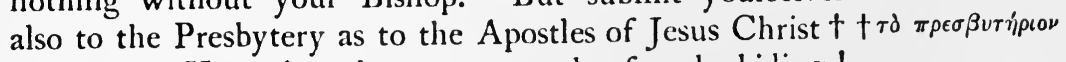
who is our Hope, in whom may we be found abiding! The Deacons also, being * ministers of the mysteries of

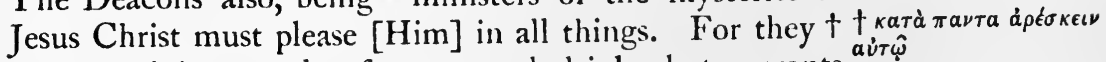
are not ministers only of meats and drinks, but servants of the Church of God. They must therefore avoid all imputations of evil as they would avoid fire."

Chap. iii. "In like manner let all reverence the deacons as a commandment of Jesus Christ; and the Bishop as Jesus Christ Himself the Son of the Father; and the Presbyters as a Council of God and as a society of apostles. Without these a Church has no right to be so called."

* $\mu \nu \sigma \tau \eta \rho l \omega \nu$. The text of the shorter recension gives $\delta \nu \tau a s ~ \mu \nu \sigma r h p c o v$

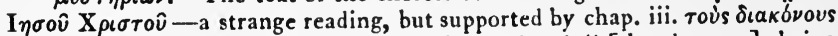

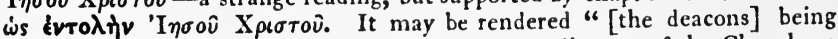
an outward visible sign of Jesus Christ," i.e., an ordinance of the Church on earth typical of an ordinance in heaven. Compare Didache xi. II, and note.

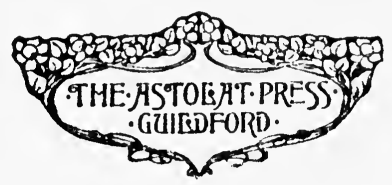



t 



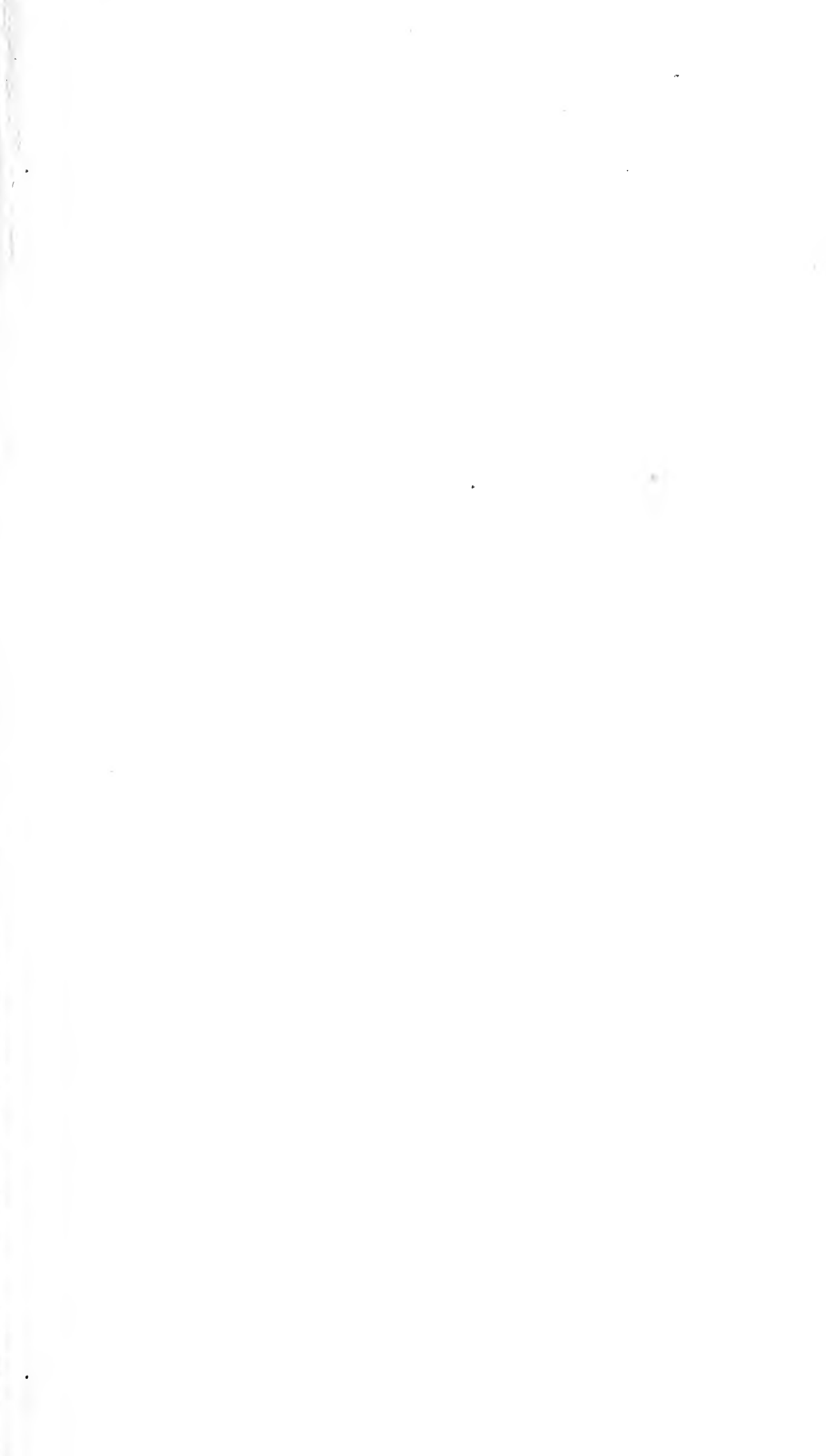




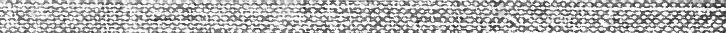

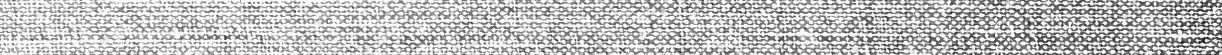

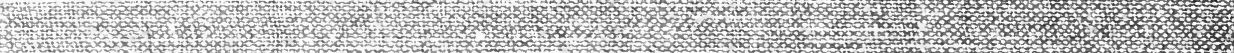

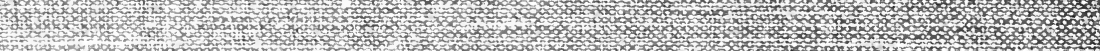

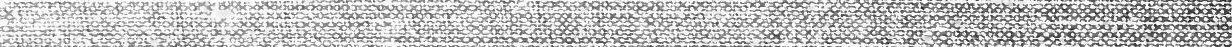

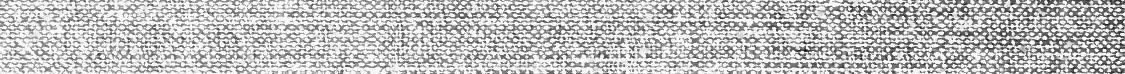

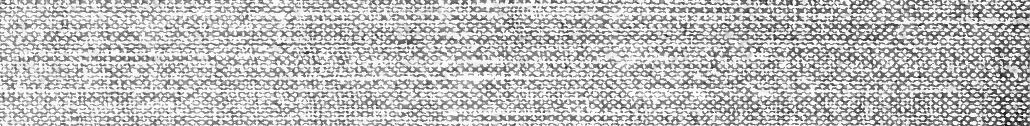

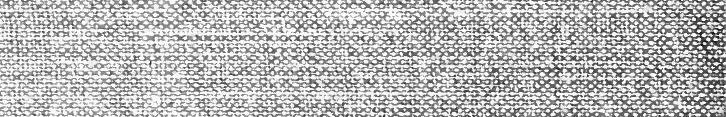

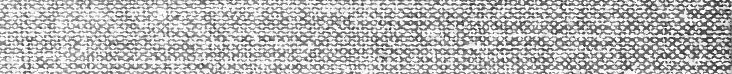

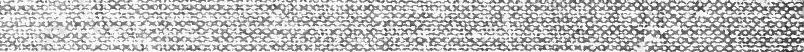
tivition

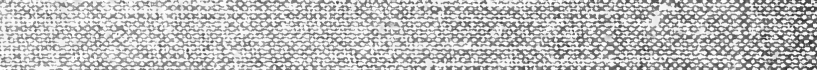

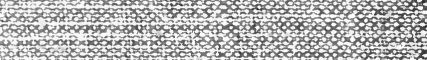

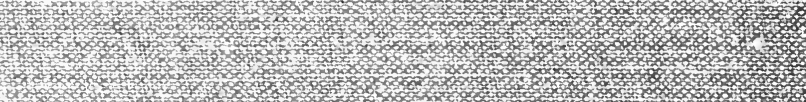

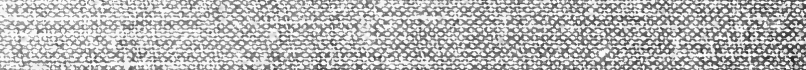

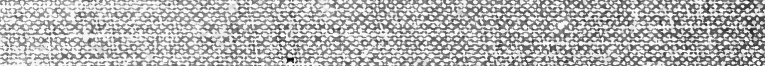

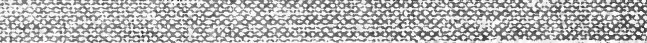

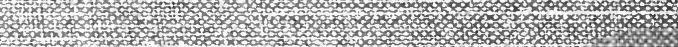

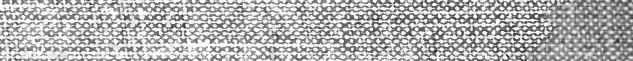
H.m. 